\title{
Mountain ranges along the European Green Belt in the Western Balkan deserve protection
}

\section{Gabriel Schwaderer}

Keywords: European Green Belt, Western Balkan, large-scale protected areas, ecological network

\section{Abstract}

The European Green Belt initiative aims to transform the former Iron Curtain into an ecological network. The most characteristic landscapes along the western part of the Balkan Green Belt are mountain ranges that are European biodiversity hotspots. The flagship species of this section of the Balkan Green Belt is the Balkan lynx, which is critically endangered. Especially the mountain ranges in the border zone between Albania, Kosovo (according UN Security Council Regulation 1244/99), Montenegro and FYR Macedonia deserve a coherent network of protected areas. The vision is to create three large complexes of transboundary protected areas. In addition to designating large-scale protected areas, the management of existing areas has to be improved significantly.

\section{The Green Belt of Europe}

The European Green Belt is an initiative to transform the route of the former Iron Curtain including the still strongly protected border between Finland and Russia into an ecological network that runs from the Barents Sea in the north to the Mediterranean and the Black Sea in the south. For centuries this line across Europe has witnessed some of the most devastating human conflicts and for decades it was also the symbol of political and ideological division between the powers of Europe. But while the Iron Curtain was a forbidden zone to people, it allowed biodiversity a 40 -year respite. Therefore the route along these borders, strictly protected for decades, includes some of the most valuable habitats and biodiversity hotspots in Europe. Based on this unique variety of natural habitats, the European Green Belt initiative aims to create a Europe-wide ecological network along the former border between East and West (IUCN 2005).

The south-eastern part of this continent-wide ecological network is known as Balkan Green Belt. Its course is more complex than in other parts of $\mathrm{Eu}$ rope. On the Balkan Peninsula, the Iron Curtain divided not only the two political blocs but more countries. Albania was completely isolated from the 1970 s onwards and its border with Yugoslavia and Greece was strictly closed and controlled. The borders of the Warsaw Pact states (Hungary, Romania and Bulgaria) with Yugoslavia and Greece were also part of the Iron Curtain. And even the border between Yugoslavia and Greece was heavily controlled (Schneider-Jacoby et al. 2006).

\section{The mountains along the western Balkan Green Belt}

The Balkan Green Belt forms an extremely heterogeneous network of mostly natural landscapes, from coastal zones, large and very specific lakes, to vast forest and steppe areas. But the most characteristic and

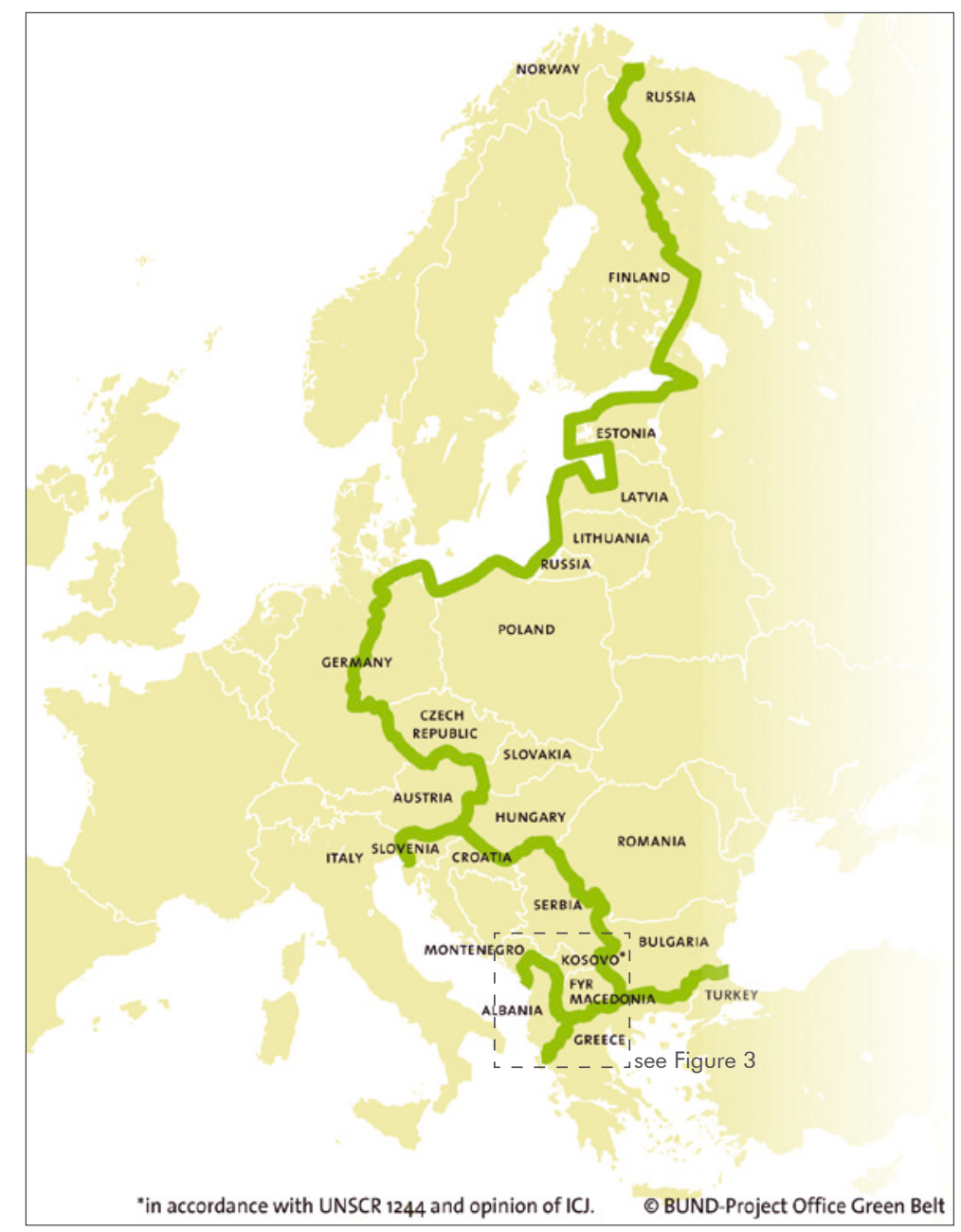

Figure 1 - The course of the European Green Belt. On the Balkean Peninsula the Green Belt follows the former borders of the Eastern Bloc, with an added Y-shape around Albania, connecting the Mediterranean with the Black Sea.

predominant landscape type of the Balkan Green Belt are mountains rising to heights of almost $2800 \mathrm{~m}$.

The most important core areas of the western Balkan Green Belt are the mountain ranges along the borders between Albania, Kosovo (UN Security Council Regulation 1244/99), Montenegro and FYR Macedo- 


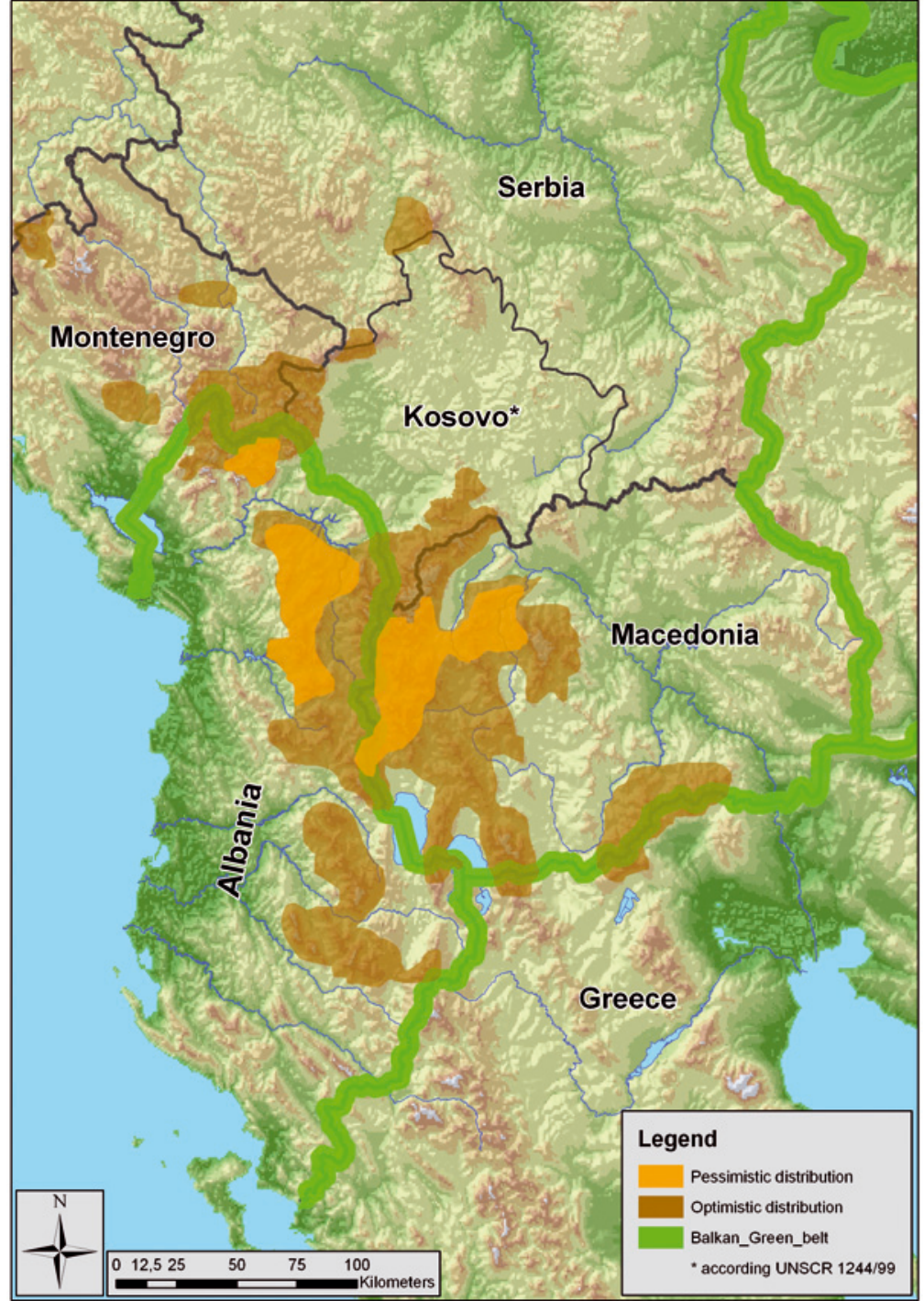

Figure 2 - The current range of the Balkan lynx is not known exactly. But the optimistic and the pessimistic distribution scenarios both emphasize the importance of the mountainous areas along the Balkan Green Belt in the Western Balkans Melovski 2012, adjusted). (C) BLRP

nia: Prokletije (ME)/Bjeshkët e Nemuna (AL and KOS), Šar Planina (MK) / Malet e Sharrit (KOS), Mali e Korabit (AL) / Golem Korab (MK) and ShebenikJabllanicë (AL) / Jablanica (MK), see Figure 3.

These mountain ranges are well connected and form a large, continuous area, in large parts only slightly altered by humans and of highest relevance for biodiversity conservation. Due to its habitat requirements, the Balkan lynx (Lynx lynx balcanicus syn. martinoi) can serve as flagship species for this important part of the European Green Belt (Schwaderer et al. 2009). The range of the critically endangered Balkan lynx (Melovski 2012) is mostly congruent with the area of the western part of the Balkan Green Belt.

The survival of the core of the Balkan lynx population can therefore only be secured through a network of protected areas covering potential lynx habitats, especially along the Balkan Green Belt. In addition, the areas between the protected areas are in need of protection and management, allowing for the recovery of habitats, the lynx prey base and the lynx population itself as well as for migration between core areas of the lynx population.

\section{Current status of protected areas}

In the priority area described above, two large-scale protected areas were designated back in former Yugoslavian times. In 1949 the Mavrovo National Park (NP) was established with an area of $117.50 \mathrm{~km}^{2}$ and only three years later, the protected area was enlarged significantly to $730.88 \mathrm{~km}^{2}$. Today the Mavrovo NP is part of the FYR Macedonia. In 1986 the Malet e Sharrit NP (Mali Sharr NP) was declared, spanning $390 \mathrm{~km}^{2}$. Today it is part of Kosovo. According to most Serbian sources, the Shar Planina NP was declared in 1993, but there is no agreement on its size: most sources quote $390 \mathrm{~km}^{2}$, others state a size of only $230 \mathrm{~km}^{2}$.

In Albania the system of protected areas was not much developed until the 1990s. After the change of the political system, a first wave of designations of protected areas took place. These areas were mostly small national parks and strict nature reserves. For this part of the Balkan Green Belt, two national parks and one strict nature reserve in Bjeshkët e Nemuna are of special importance. Theth NP was designated in 1966 but covers only $26.30 \mathrm{~km}^{2}$. The adjacent Valbona NP was declared in 1996 and has about $80 \mathrm{~km}^{2}$. Gashi River Nature Reserve, which covers an area of $30 \mathrm{~km}^{2}$, was also designated in 1996.

In the Montenegrin part of this mountain range, Prokletije NP was established in 2009 and stretches across $160.38 \mathrm{~km}^{2}$.

In recent years, several initiatives were started in all four countries in order to enlarge the existing transboundary network of protected areas. The most consistent approach in that respect was initiated in 2005. The Balkan Lynx Recovery Programme (BLRP), which is organized jointly by the EuroNatur Foundation, the Macedonian Ecological Society (MES), Protection and Preservation of Natural Environment in Albania (PPNEA) and KORA from Switzerland, aims at protecting the critically endangered Balkan lynx and its habitat. Therefore the implementing organizations proposed to the governments in Albania and Macedonia to proclaim significant parts of their share of the Balkan Green Belt as protected areas in order to safeguard the core range of the Balkan lynx habitat. As a first success of the joint efforts, Albania proclaimed the Shebenik-Jabllanicë NP north of Lake Ohrid in 2008 with a total surface of $339.28 \mathrm{~km}^{2}$. In 2011 the Korab-Koritnik Regional Nature Park north of the town of Peshkopi followed with a size of $555.50 \mathrm{~km}^{2}$. 
Further challenges for the creation of a coherent network of protected areas

Beside the above mentioned approach of the BLRP, UNEP conducted several feasibility studies on establishing transboundary protected areas on the Balkan Peninsula. For the region Sharr / Šar Planina - Korab - Dešat/Deshat, the study suggests a total surface of protected areas with a size of more than $2550 \mathrm{~km}^{2}$ (UNEP 2010 a) covering parts of Albania, Kosovo and FYR Macedonia. More than $1650 \mathrm{~km}^{2}$ of this area are already designated as protected areas. In Kosovo an extension of the Mali Sharr NP is currently under discussion, which would mean an additional area of 80 to $600 \mathrm{~km}^{2}$. In FYR Macedonia several attempts, especially by MES, were made to advance the designation of a Shar Planina NP with a size of approximately 500 to $600 \mathrm{~km}^{2}$. If these efforts are successful, they will create a network of protected areas of more than $2550 \mathrm{~km}^{2}$ in total.

For the area of Prokletije / Bjeshkët e Nemuna, the UNEP feasibility study suggests a network of protected areas with a total size of more than $2050 \mathrm{~km}^{2}$ (UNEP 2010 b) of which currently only about $300 \mathrm{~km}^{2}$ are protected.

Although considerable progress is evident with respect to the enlargement of the network of protected areas, it is still a long way from creating a functioning, coherent and consistent network of protected areas along the mountains in the western part of the Balkan Green Belt.

One suggestion envisaged merging the existing national parks and the strict nature reserve into one largescale protected area in Bjeshkët e Nemuna within the framework of the BLRP. Unfortunately, this proposal has not been taken up by the responsible authorities so far, mainly because a high number of districts and municipalities would be affected by such a plan. But the natural qualities of the respective area urgently need to be covered by a protection status. To achieve that, the Albanian authorities should be encouraged to proclaim a national park of at least $1000 \mathrm{~km}^{2}$.

There are also setbacks in the process towards establishing a transboundary network of protected areas along the Balkan Green Belt. In Montenegro the Prokletije NP has been established on a much smaller area than originally planned, and the designations of the Komovi Nature Park and two more regional parks are still pending.

The plans to establish the Bjeshkët e Nemuna NP in Kosovo date back to the 1970s and originally envisaged an area of almost $1000 \mathrm{~km}^{2}$. Currently there is a controversy in Kosovo about the establishment of this national park and its size which will be probably result in a much smaller park than in the original plans.

Still pending is a decision of the Macedonian authorities on an application for the designation of Jablanica NP, which was submitted by MES in 2007, supported by the local governments. The proposed

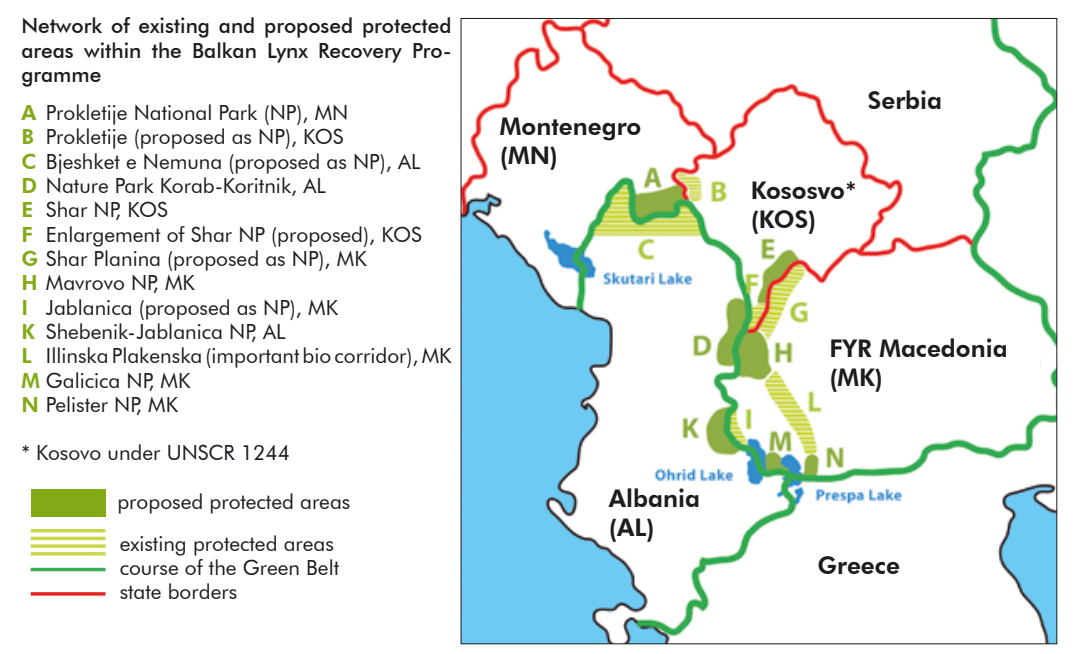

Figure 3 - Network of existing and proposed protected areas within the framework of the BLRP along the Balkan Green Belt. (C) EuroNatur

Jablanica NP would cover an area of about $160 \mathrm{~km}^{2}$. Together with the already existing Shebenik-Jabllanicë NP in Albania, it would form a transboundary protected area of about $500 \mathrm{~km}^{2}$.

\section{Improvements required in the management of protected areas}

Apart from the lack of cohesion in the current network of protected areas in the mountain ranges along the Balkan Green Belt, the weak management of existing protected areas must be seen as a serious obstacle for the successful protection of natural landscapes. Addressing these management deficiencies is particularly pressing as severe threats are under way, e.g. the infrastructure projects at the edges and even within the territory of protected areas.

Most of the large-scale protected areas lack qualified staff and necessary equipment. In Prokletije NP in Montenegro, a director has been appointed but no additional staff and equipment is available.

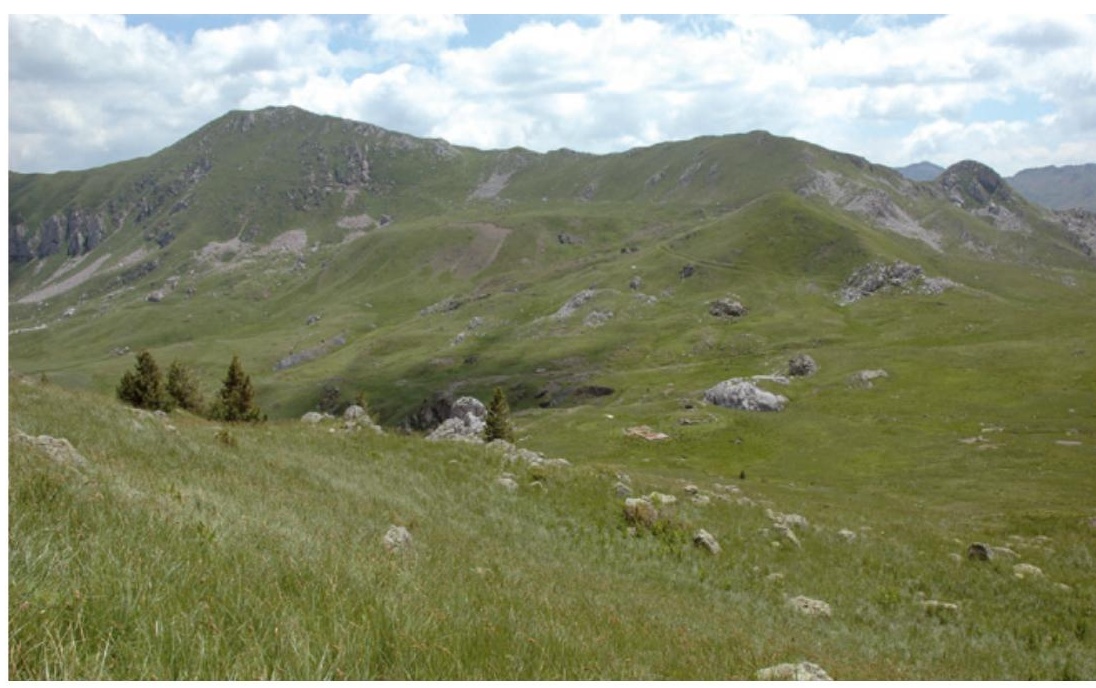

Figure 4 - The Jablanica mountains form the border between Albania and Macedonia and are part of the Balkan Green Belt. (C) Gabriel Schwaderer 
The situation is similar in Albania. Valbona NP, which currently faces severe threats, has no administration at all. Consequently, nobody can protect the Valbona valley against the various interests attracted by its unique natural resources. The current construction of a new road along the Valbona River is a major negative impact for the valley. Apparently there are also plans to connect the valleys of Valbona and Thethi with a tunnel. These developments in the beautiful valleys will lead to increased pressure on the region from tourism. Given the weak spatial planning system in Albania, it is likely that both valleys will undergo a dramatic change in the next few years, with an uncontrolled growth of settlements and hotels.

These developments reflect the situation in most protected areas in Albania, which are characterized by the absence of an administration and a management plan. Not only the Valbona NP, but also many other protected areas in Albania have to be considered paper parks. So far this is also true of Shebenik-Jabllanicë NP. Currently a project implemented by IUCN, jointly with PPNEA, aims to prepare the ground for the effective management of this national park. In the medium and longer term, the Albanian state has to establish well equipped administrative bodies with qualified and dedicated staff to safeguard the natural qualities of the Balkan Green Belt.

However, even the presence of administrative bodies does not guarantee effective management of protected areas. In Mali Sharr NP, which possesses an administration of qualified and dedicated staff, the Kosovo government pushes plans like the construction of a huge ski resort in the core zone of the national park.

The Mavrovo NP is the oldest large-scale protected area in the area in question. Its administrative structures are quite advanced, with a level of staffing appropriate for a national park of this size. But in Macedonia, too, protected areas face severe problems: first, national park administrations do not receive a substantial budget from the responsible ministry but have to cover their expenses through the sale of goods and licenses. As a result, logging and hunting is common in national parks. Secondly, politicians often intervene in the management of national parks. A very serious example is the currently planned construction of two large hydro-electric power plants in Mavrovo NP.

\section{Outlook}

The mountain ranges along the European Green Belt in the Western Balkan are characterized by their tremendous natural values. In order to preserve these biodiversity hotspots it has been suggested to create three large complexes of transboundary protected areas connected by corridors. Considerable progress towards a coherent ecological network has been achieved to date, but the designation of further national parks and large-scale protected areas is strongly recommend- ed to create a network. Additionally, the management of the existing protected areas requires significant improvement. A coherent and well managed network of protected areas is the precondition for preserving this essential part of the European Green Belt and an important contribution to the recovery of the Balkan lynx. It could also serve as a potential backbone for an Emerald and Natura 2000 network.

\section{References}

Melovski, D. 2012. Status and distribution of the Balkan lynx (Lynx lynx martinoi Miric, 1978) and its prey. Podgorica. Unpublished master thesis.

Schneider-Jacoby, M., G. Schwaderer \& W. Fremuth 2006. The South-Eastern European Green Belt. In: Terry, A., U. Riecken \& K. Ullrich (eds.), The Green Belt of Europe: From Vision to Reality. IUCN, Gland, Switzerland and Cambridge, UK: 61-76.

Schwaderer, G., A. Spangenberg, M. Schneider-Jacoby \& G. Willinger 2009. Grünes Band Balkan als Lebensraum für bedrohte Arten. Natur und Landschaft. Zeitschrift für Naturschutz, und Landschaftspflege 84 (9/10): 420-425.

IUCN 2005. Programme of Work for the European Green Belt. Belgrade. Unpublished document.

UNEP 2010 a. Feasibility study on establishing a transboundary protected area Sharr/Śar Planina - Korab Dešat / Deshat. UNEP Vienna - ISCC.

UNEP 2010 b. Feasibility study on establishing a transboundary protected area Prokletije/Bjeshkët e Nemuna Mountains. UNEP Vienna - ISCC.

\section{Author}

Gabriel Schwaderer, Executive Director, EuroNatur Foundation, Germany

Gabriel Schwaderer graduated with a degree in geography. He has more than 20 years of experience in protected area management, nature conservation and sustainable regional development. His expert knowledge is in the areas of conservation of large carnivores and creating strategies for regional sustainable development. 